GENDER STUDIES 20(1)/2021

\title{
sciendo
}

\subsection{8/genst-2022-0010}

\section{ON DICTIONARIES AND GENDER REPRESENTATIONS}

\author{
RUXANDRA VIȘAN \\ University of Bucharest \\ ruxandra.visan@1ls.unibuc.ro
}

\begin{abstract}
Placed at the interface between metalexicography and gender studies, this short article discusses issues concerning gender representations in present-day dictionaries. Evoking recent controversies regarding the representation of genderrelated terms such as "cisgender" or "woman" in The Oxford English Dictionary, the essay goes on to discuss the prescriptive/descriptive opposition concerning lexicographical representations, taking its cue from previous approaches, which suggest re-envisaging the prescriptive/descriptive dyad as a continuum (Straaijer, 2009; Wilton 2014), or replacing this traditional binary model with a nonbinary approach (Nossem, 2018; Turton, 2020).
\end{abstract}

Keywords: dictionary, metalexicography, gender representations, prescriptive, descriptive, normativity.

\section{Introduction: A dictionary's inclusiveness}

Even if digital dictionary apps are becoming more commonly used than print dictionaries, the need to look a word up remains ever so present, whether we simply google that word, or whether we use the online Merriam Webster and the humorous, irreverent, and at times unreliable Urban Dictionary. When we look a word up, we expect to find it registered in a dictionary, and we sometimes become frustrated and disappointed if dictionaries do not choose to include a particular lexical item we came across. Born in the eighteenth century, "universal" dictionaries were engendered by an aspiration towards comprehensiveness, that of including as many words as possible for the reading public of the time. We still measure general-purpose dictionaries (and even bilingual or learner's dictionaries) by this "bigger/better" standard of comprehensiveness, and expect them to register as much as possible of the lexis of a language. 


\section{GENDER STUDIES 20(1)/2021}

This is why it is perhaps not surprising that after The Oxford English Dictionary (OED) added the word cisgender to its list of words in 2013, one of the reactions was that expressed in The Cut (part of the The New York Magazine) by Erica Schwiegershausen, in a 2015 article entitled “Wait, Cisgender Wasn't in the Oxford English Dictionary Already?”. Yet the question "Why wasn't cisgender already in the OED?" did not arise only due to an aspiration towards lexicographical comprehensiveness, but because, as dictionary-users, we still envisage these dictionaries not as bland repositories of words, but as something more than that - as points of reference in the representation of our (linguistic) world. From this point of view, the definition of cisgender adopted by the OED ("Cisgender (adj.): Designating a person whose sense of personal identity and gender corresponds to his or her sex at birth; of or relating to such persons. Contrasted with transgender." - Oxford English Dictionary, 2019) shifts the focus away from the heterosexual/LGBTQI dichotomy (where heterosexual emerges as the unmarked term). Certainly, terms such as cisgender challenge previously established "norms", and the question of normativity is a particularly interesting one if we focus on dictionaries.

\section{Normativity, neutrality and revisability}

Dictionaries acquired a normative function in the eighteenth century ("the age of prescriptivism") and in spite of the shift towards the descriptive approach embodied by late nineteenth-century/ early twentieth-century texts such as The Oxford English Dictionary, where the proposal was to register words without judgement (as was pointed out in a nineteenthcentury text which lies at the foundation of the $O E D$, "it is no task of the maker to select the good words of a language", Trench, 1860, p. 60), the normative function is still something which current dictionary-users expect their dictionaries to fulfil, irrespective if the dictionary authors themselves conceive of their text as prescriptive or not (see Béjoint 2014 among others). A relevant example in this respect is a recent controversy which arose regarding the synonyms and examples for the entry for woman in the $O E D$, when a considerable number of people petitioned the publishers to exclude what were seen as "derogatory synonyms" (among which "bird" or "bitch") from its entry for woman (see Flood, 2019). According to The Guardian (Flood, 2020), the spokesperson for Oxford University Press stressed in response to the criticism that the purpose of the $O E D$ was "to reflect rather than dictate how language is used" and to provide "an accurate representation of language". This answer is certainly meant to underline the strongly "descriptive" premise underlying the $O E D$, which, at the time of its creation, firmly rejected the prescriptivism of earlier lexicographical texts (At the turn of the 
twentieth century, the $O E D$ editor James Murray characterized the desire to fix the language of the lexicographers of the eighteenth century as "childlike and pathetic", Murray, 1900, p. 13). Nevertheless, while, in response to recent criticism, the $O E D$ publishers emphasized that their purpose was to register language, and not to make linguistic prescriptions, they did assure the public that an "extensive review" had already been undertaken regarding the entry for woman and other related terms (see Flood, 2020). Moreover, recent blog posts on the OED website focus on the historical contributions of women to the $O E D$ or on how $O E D$ lexicographers make use of LGBT resources in history. This underlines that the $O E D$ publishers are well aware that their dictionary emerges not only as an inventory of language, but also as a sociohistorical representation of various communities and of linguistic varieties, and at the same time as a potential means of not only illustrating, but also of validating and legitimizing various ideologies.

Previous researchers have stressed that neutrality in lexicography is an "unattainable ideal" (Mugglestone, 2005, p. 87), since no dictionary can in fact function as a completely objective record of language. Moreover, let us recall that present-day dictionaries, which may not be overtly normative, do include usage labels (such as "taboo", "slang" or "vulgar"), and are still employed as points of reference in courts of law, state documents or regulations regarding discrimination and hate speech. Since dictionaries do not in fact function only as descriptive records which register language in flux, but also as normative texts produced by a certain sociocultural context, it is no wonder why users set so much store by the representation of gender-related terms such as woman or cisgender. The style and structure of the definitions, as well as the usage notes and the examples selected to illustrate such headwords emerge in fact as a relevant part of gender representations. In the same manner, on a macrostructural level, it becomes quite relevant for the study of gender representations to examine what words dictionaries (which can only function as relevant selections of language and not as language in its totality) choose to include, as well as what they choose to exclude from their list. For example, an examination of the current Explanatory Dictionary of the Romanian Language ( " $D E X$ ”), the most used general-purpose dictionary of Present-Day Romanian, is characterized by the conspicuous absence of terms such as gay or homofob (English homophobe), in spite of the current frequency of usage of such lexical items.

As can be seen, due to their special status as reference books, dictionaries cannot function in the eyes of their (non-specialist) users only as inventories of language, but can be also read as texts prescribing certain norms of usage, as male hegemonic texts (Interestingly, one of the complaints of those who petitioned regarding the entry for woman in the $O E D$ was that it was less extensive than that for man) or as heteronormative texts which choose to exclude 
words such as gay or cisgender. Dictionaries do not function however only as definitive reference books, but as perpetually "open" texts, which are subject to revisions and constant updates, since language changes continuously (at its interface with society). It is thus perhaps no wonder why users often critique such lexicographical texts, and it is perhaps relevant that the present digital era allows for revisions and updates at a considerably faster pace than previous times. While they (partly) retain the normative function they acquired in the eighteenth century, present-day dictionaries now emerge as easily "revisable", and thus as more fluid and as less immutable than in previous eras.

\section{Conclusions: Descriptive, prescriptive and beyond}

Recent approaches centring on metalexicography, which include a gender studies dimension, have attempted to look at dictionaries in a way which means to shift focus away from dictionaries authored predominantly by male authors (Johnson, Webster, etc.), by recuperating the role of female lexicographers in the representation of language, as does Russell (2018) in her book, Women and Dictionary-Making. Gender, Genre and English Language Lexicography. Other researchers, such as Nossem (2018) have questioned the normalized practices which lead to dictionary-making and have examined the relation between lexicographical representations and heteronormativity. In the same direction of "queering lexicography" (see Nossem, 2018), Turton (2020) proposes a theoretical approach influenced by performativity theory, which aims to replace the traditional binary model descriptive/prescriptive with a nonbinary one.

The creators who laid the foundations of The Oxford English Dictionary conceived of a clear-cut divide between their descriptive aims (that of objectively registering language) and the prescriptive aims of previous lexicographers (that of setting language norms and of expressing certain attitudes to language). However, with their focus on defining and on labelling, on selecting and on ordering, dictionaries emerge in the end as both descriptive and prescriptive at the same time. As previous researchers have emphasized, prescriptivism and descriptivism should be considered part of a continuum, rather than diametrical opposites (see Straaijer, 2009), and the fact that dictionaries cannot function in a purely prescriptive or in a purely descriptive manner emphasizes that it is time to rethink the prescriptive/descriptive dyad (see Wilton, 2014). I believe that by acknowledging the prescriptive/descriptive dimensions in their fluid continuity in the history of linguistics, rather than as a sharp opposition, we have 


\section{GENDER STUDIES 20(1)/2021}

indeed a better chance to understand the complex role of dictionaries, and to examine the mechanisms underlying lexicographical representations, including those related to gender.

\section{References}

Béjoint, H. ( 2010). The Lexicography of English. Oxford University Press.

Flood, A. (2019, September 17). Thousands demand Oxford dictionaries "eliminate sexist definitions." The Guardian. Retrieved from https://amp.theguardian.com/books/ 2019/sep/17/thousands-demand-oxforddictionaries-eliminate-sexist-definitions. [Accessed 2021, December 1].

Flood, A. (2020, March 3). Fresh call for Oxford dictionaries to change "sexist" definitions. The Guardian. Retrieved from https://www.theguardian.com/books/2020/mar/03/ fresh-call-for-oxford-dictionaries-tochange-sexist-definitions [Accessed 2021, December 1].

Mugglestone, L. (2005). Lost for words, The hidden history of the Oxford English Dictionary. Yale University Press.

Murray, J. (1900). The evolution of English lexicography. Oxford: Clarendon Press.

Nossem, E. (2018). Queering lexicography: balancing power relations in dictionaries. In B. J. Baer \& K. Kaindl (Eds.), Queering Translation, Translating the Queer: Theory, Practice, Activism (pp.172-187). Routledge.

Oxford English Dictionary. (2019, $3^{\text {rd }}$ ed.). Cisgender. Retrieved from https://www.oed.com/ [Accessed 2020, March 17].

Oxford English Dictionary. (2019, $3^{\text {rd }}$ ed.). Woman. Retrieved from https://www.oed.com/ [Accessed 2020, March 17].

Russell, L. R. (2018). Women and dictionary-making. Gender, genre and English language lexicography. Oxford University Press.

Schwiegershausen, E. (2015, June 25). Wait, cisgender wasn't in the Oxford English dictionary already? The Cut. Retrieved from https://www.thecut.com/2015/06/wait-cisgender-wasnt-in-the-oed-already.html. [Accessed 2021, December 1].

Straaijer, R. (2009). Deontic and epistemic modals as indicators of prescriptive and descriptive language in the grammars of Joseph Priestley and Robert Lowth. In I. Tieken-Boon van Ostade \& W. van der Wurff (Eds.), Current Issues in Late Modern English (pp. 57-87). Peter Lang.

The Romanian Academy. (2016, Revised 2 ${ }^{\text {nd }}$ ed.). DEX. Dicționarul explicativ al limbii române [The Explanatory Dictionary of the Romanian Language]. Univers Enciclopedic.

Trench, R. C. (1860, Revised $2^{\text {nd }}$ ed.). On some deficiencies in our English dictionaries. John W. Parker \& Sons.

Turton, S. (2020). Redefining realness: bringing queer performativity to the English dictionary. Journal of Language and Sexuality, 9(2), 101-126.

Wilton, David. (2014). Rethinking the prescriptivist-descriptivist dyad: Motives and methods in two eighteenthcentury grammars. English Today, 30(3), 38-47.

Ruxandra VIȘAN is Professor of English at the University of Bucharest. Her main research interests lie in the direction of historical sociolinguistics, history of lexicography and language ideology. She is particularly preoccupied by the interface between language ideology and the history of ideas, and she has published works focusing on dictionaries, translations or language complaints. 